\title{
Epigenetic Alterations in Cholangiocarcinoma- Sustained IL-6/STAT3 Signaling in Cholangio- carcinoma due to SOCS3 Epigenetic Silencing
}

\author{
Hajime Isomoto \\ Department of Endoscopy, Nagasaki University Hospital of Medicine and Dentistry, Nagasaki, Japan
}

\section{Key Words}

Cholangiocarcinoma - Epigenetics • DNA hypermethylation • Carcinogenesis - Suppressor of cytokine signaling 3 •

Interleukin- $6 \cdot$ Signal transducers and activators of transcription 3

\begin{abstract}
Cholangiocarcinoma (CCA) is a highly lethal malignant tumor arising from the biliary tract epithelium, characterized by its typically late clinical presentation and lack of effective therapeutic modalities. Chronic inflammatory conditions, including primary sclerosing cholangitis, liver fluke infestation and hepatolithiasis, are listed in the risk factors, but for most cases of CCA the cause is unknown. Recent advances in molecular pathogenesis have highlighted the importance of epigenetic alterations including promoter hypermethylation and histone deacetylation in addition to genetic changes in the process of cholangiocarcinogenesis. This review provides a comprehensive overview of the genes hypermethylated in CCA to date and their putative roles in cholangiocarcinogenesis. Among genes hypermethylated, we found the $\mathrm{CpG}$ island hypermethylation in suppressor of cytokine signaling 3 (SOCS3) gene promoter in CCA. Interleukin-6 (IL-6)-mediated signal transducers and activators of transcription 3 (STAT3) activation are aberrantly sustained in CCA cells, resulting in resistance to apoptosis. SOCS3 controls the IL-6/STAT3 signaling pathway by a classic feedback loop. Indeed, SOCS3 epigenetic silencing is responsible for
\end{abstract}

sustained IL-6/STAT3 signaling in CCA. These findings provide new perspectives for epigenetic therapy to restore SOCS3 in this cancer.

Copyright $\odot 2009$ S. Karger AG, Basel

\section{Introduction}

Cholangiocarcinoma (CCA) is a devastating neoplasm originating from cholangiocytes, the epithelial cells that line the biliary apparatus [1]. It comprises only $10-15 \%$ of hepatobiliary neoplasm $[2,3]$. Two thirds of CCA involve the extrahepatic bile duct, whereas the remaining third affects the intrahepatic biliary tree $[1,4]$. The disease is notoriously difficult to diagnose and is usually fatal because of its typically late clinical presentation and the lack of effective therapeutic modalities [1,4]. Most patients have unresectable disease at presentation and the overall survival rate including resected patients is poor, with less than $5 \%$ of patients surviving 5 years [5]. Although CCA is a relatively rare tumor, interest in this disease is rising as the incidence and mortality rates are increasing worldwide $[2,3]$. CCA is associated with chronic inflammatory conditions of the biliary system including hepatolithiasis, liver fluke infestation, choledochal cysts and primary sclerosing cholangitis $[1,4]$. However, for most CCA cases the cause is unknown, and affected individuals have no history of exposure to or association with such risk factors $[1,4]$.

\section{KARGER}

Fax +41613061234 E-Mail karger@karger.ch www.karger.com (c) 2009 S. Karger AG, Basel

$0012-2823 / 09 / 0795-0002 \$ 26.00 / 0$

Accessible online at:

www.karger.com/dig
Hajime Isomoto, MD

Department of Endoscopy, Nagasaki University Hospital of Medicine and Dentistry 1-7-1 Sakamoto

Nagasaki 852-8501 (Japan)

Tel. +81 95819 7337, Fax +8195819 7568, E-Mail hajimei2002@yahoo.co.jp 
At present, little is known about molecular mechanisms in CCA. As for many other tumors, the development of CCA must also be understood as a multistep process, with the accumulation of genetic and epigenetic alterations in regulatory genes, leading to the activation of oncogenes and the inactivation or loss of tumor suppressor genes (TSGs) [6]. This review discusses the epigenetic inactivation of different TSGs in CCA.

\section{Genetic Alterations in CCA}

The milieu of chronic biliary inflammation, along with cholestasis, leads to the production of cytokines and reactive oxygen species, and this causes protracted cellular stresses and irreversible DNA damage $[1,2]$. As a result, cholangiocytes attain cellular phenotypes that result in malignant transformation [1]. The proposed pathways that partake in cholangiocarcinogenesis include: self-sufficiency and proliferation; apoptosis resistance; escape from senescence and tumor invasiveness and metastasis [1]. Molecular mechanisms responsible for the bile duct carcinogenesis likely include the interaction of genetic variants and somatic cell alterations $[1,4,6]$. The genetic changes in CCA include: mutations of K-ras, p53, p16 ${ }^{\mathrm{INK} 4 \mathrm{a}}$ and Smad4; loss of heterozygosity of APC; allelic losses on 3p13-p21 and 8q22 [7-11]. Among the genetic abnormalities that have been demonstrated in CCA, p53 mutations and activating K-ras mutations are the most frequent [6]. Nevertheless, the reported rates of genetic alterations in CCA vary widely among studies $[4,6]$. These variations are presumably owing to differences in the subsites of cancers, racial and geographical variations in the study populations and the use of different assay techniques [4].

\section{Epigenetic Alterations in CCA}

\section{Histone Modifications}

Histones are basic proteins that complex with genomic DNA to form nucleosomes, the basic units of the compacted structure of chromatin. Histones are modified posttranslationally by acetylation, methylation and phosphorylation. Histone acetylation appears to be the major means of regulation of histone function. Histones are acetylated on lysine residues at their amino termini by histone acetyltransferases and acetylated histones are deacetylated by histone deacetylases (HDACs). The HDAC-mediated removal of acetyl groups from lysine residues in the amino termini of histones leads to chromatin condensation and transcriptional inactivation of the involved DNA $[12,13]$. This transcriptional inactivation can contribute to suppression of TSG expression and enhanced tumorigenesis [14]. In fact, HDAC inhibitors enhance the acetylation state of histones, leading to chromatin decondensation and increased gene expression $[15$, 16]. HDAC inhibitors can therefore reverse the aberrant epigenetic state associated with cancer and have been shown to act in synergy with DNA methylation inhibitors to inhibit tumor growth $[15,16]$. There is, nevertheless, nominal information on the etiologic roles of histone modifications in cholangiocarcinogenesis.

\section{DNA Methylation}

DNA methylation refers to the addition of a methyl group to 1 of the 4 bases that constitute the coding sequence of DNA $[17,18]$. DNA methylation plays a key role in chromatin structure, suppression of the activity of endogenous parasitic sequences and stable suppression of gene expression (epigenetic silencing), a process normally reserved for special situations such as the inactive $\mathrm{X}$ chromosome and imprinted genes $[19,20]$. DNA methylation occurs via the covalent addition of a methyl group to the 5-position of the cytosine ring within the context of a cy tosine nucleotide followed by a guanine nucleotide (CpG dinucleotide or CpG site) [18]. It has been estimated that almost half of the human gene promoter regions contain the CpG-rich regions, called CpG islands [21, 22]. Promoter hypermethylation of $\mathrm{CpG}$ islands results in downregulation or silencing of gene transcription, and thus the aberrant promoter hypermethylation of TSGs is an alternative mechanism of gene inactivation that contributes to the carcinogenesis of human neoplasms including CCA $[4,6,22]$.

\section{Genes Hypermethylated in CCA}

Genes hypermethylated in the promoter $\mathrm{CpG}$ islands in CCA are summarized in table 1. TSGs through epigenetic silencing are involved in important molecular pathways of cholangiocarcinogenesis, such as cell-cycle regulation, apoptosis, DNA repair and cell adhesion [23], and are herein reviewed in brief.

p16 ${ }^{\text {INK4A }}$, also called cyclin-dependent kinase inhibitor $2 \mathrm{~A}$, is a TSG located at human chromosome 9p21 and inhibits their interaction with cyclin D1 [24]. This TSG is frequently inactivated in a variety of tumors by deletion, mutations and promoter hypermethylation [6]. In CCA, CpG island methylation appeared to be the main cause of p16 ${ }^{\mathrm{INK} 4 \mathrm{a}}$ inactivation despite variable methylation fre- 
Table 1. Promoter hypermethylation frequencies in various genes in cholangiocarcinoma

\begin{tabular}{|c|c|c|c|c|}
\hline Gene & Location & Function & Incidence, \% & Reference \\
\hline $\mathrm{p} 14^{\mathrm{ARF}}$ & $9 \mathrm{p} 21$ & cell cycle regulation & $25-38$ & 28,32 \\
\hline $\mathrm{p} 15^{\mathrm{INK} 4 \mathrm{~b}}$ & $9 \mathrm{p} 21$ & cell cycle regulation & 50 & 28 \\
\hline $\mathrm{p} 16^{\mathrm{INK} 4 \mathrm{a}}$ & $9 \mathrm{p} 21$ & cell cycle regulation & $18-83$ & $\begin{array}{l}25,26,27,28 \\
29,30,31,32\end{array}$ \\
\hline p73 & $1 \mathrm{p} 36.3$ & cell cycle regulation & $36-49$ & 28 \\
\hline RASSF1A & $3 p 21.3$ & cell cycle regulation & $27-69$ & $26,28,33,34$ \\
\hline DAPK & $9 q 34.1$ & apoptosis & $3-32$ & $26,28,30$ \\
\hline TMS1/ASC & $16 \mathrm{p} 11.2$ & apoptosis & 5 & 36 \\
\hline SEMA3B & 3 p21.3 & apoptosis & 100 & 37 \\
\hline 14X3X3 & $1 \mathrm{p} 36.11$ & apoptosis & 60 & 25 \\
\hline RUNX3 & $1 \mathrm{p} 36$ & apoptosis & 57 & 26 \\
\hline CHFR & $12 \mathrm{q} 24.33$ & apoptosis & 16 & 26 \\
\hline hMLH1 & $3 \mathrm{p} 21.3$ & DNA repair & $8-46$ & $26,28,30,40,41$ \\
\hline MGMT & $10 q 26$ & DNA repair & $33-49$ & 28,30 \\
\hline RAR $\beta 2$ & $3 \mathrm{p} 24.2$ & cell growth and differentiation & 14 & 28 \\
\hline APC & $5 q 21$ & cell adhesion & $27-46$ & 25,28 \\
\hline E-cadherin & $16 \mathrm{q} 22.1$ & cell adhesion & $22-43$ & $25,26,28,30$ \\
\hline TIMP3 & $22 \mathrm{q} 12.1$ & cell adhesion & 9 & 25,28 \\
\hline THBS1 & $15 \mathrm{q} 15$ & cell adhesion & 11 & 25,37 \\
\hline GSTP1 & $11 \mathrm{q} 13$ & drug/xenobiotic metabolism & 14 & 28 \\
\hline FHIT & $3 q 14.2$ & purine metabolism & 42 & 33 \\
\hline SOCS3 & $17 q 25.3$ & cytokine signaling & 88 & 45 \\
\hline MINT1 & $22 \mathrm{q} 11$ & unknown & 41 & 25 \\
\hline MINT12 & $22 \mathrm{q} 11$ & unknown & 51 & 25 \\
\hline MINT25 & $22 \mathrm{q} 11$ & unknown & 15 & 25 \\
\hline MINT31 & $22 \mathrm{q} 11$ & unknown & 1 & 25 \\
\hline MINT32 & $22 \mathrm{q} 11$ & unknown & 35 & 25 \\
\hline BLU & $3 \mathrm{p} 21.3$ & unknown & 20 & 37 \\
\hline
\end{tabular}

quencies [25-32]. This promoter region hypermethylation has been shown to be associated with a poor clinical outcome. The DNA methylation frequencies of other genes related to cell cycle regulation, including $\mathrm{p} 14^{\mathrm{ARF}}$ $[28,32], \mathrm{p} 15^{\mathrm{INK} 4 \mathrm{~b}}[28], \mathrm{p} 73$ [28] and Ras association domain family $1 \mathrm{~A}$ (RASSF1A) [26, 28, 33, 34], as well as their chromosomal locations are shown in table 1.

Death-associated protein kinase (DAPK) gene is located at chromosome $9 \mathrm{q} 34.1$ and its product is a proapoptotic mediator of IFN- $\gamma$-induced programmed cell death $[4,35]$. The DNA methylation frequencies ranged from 3 to $32 \%$ in CCA $[26,28,30]$. This promoter hypermethylation is likely to be associated with poorly differentiated CCA and poor prognosis $[26,28]$. The DNA methylation frequencies of other genes related to apoptosis, including target of methylation-mediated silencing/apoptosis speck-like protein containing a caspase recruit domain (TMS1/ASC) [36], semaphorin 3B (SEMA3B) [37], 14-3-3 [25], Runt-related transcription factor 3 (RUNX3) [26] and checkpoint with forkhead and ring finger domains
(CHFR) [26], as well as their chromosomal locations are shown in table 1.

Human mutL homologue 1 (hMLH1) is a DNA mismatch repair gene located at 3p21.3 [38]. Genetic and epigenetic alterations of hMLH1 have been reported in various cancers $[38,39]$. In CCA, DNA methylation frequencies of the hMLH1 gene promoter varied $0-46 \%[26,28$, 30, 40, 41]. Limpaiboon et al. [41] found an association between this promoter hypermethylation and the poorly differentiated CCA with vascular invasion. $\mathrm{O}^{6}$-methylguanine-DNA methyltransferase (MGMT) gene is located at chromosome 10q26. This gene is responsible for repairing alkylation DNA damage [42]. Koga et al. [30] found a high methylation frequency of $49 \%$ in MGMT gene, whereas Yang et al. [28] reported a 33\% methylation frequency of MGMT gene in CCA. This promoter hypermethylation can be associated with an increased frequency of GC to AT transitions in oncogenes and TSGs and with a poor prognosis [30]. 
Epithelial cadherin (E-cadherin) gene is located at chromosome 16q22.1. The encoded protein is a calciumdependent cell adhesion molecule [43]. Genetic and epigenetic alterations in this gene lead to loss of function, permitting progression of cancer by increasing proliferation, invasion and metastasis $[4,43]$. DNA methylation frequencies of this gene in CCA ranged from 22 to $43 \%$ $[25,26,28,30]$. Adenomatous polyposis coli (APC) gene is located at $5 \mathrm{q} 21-\mathrm{q} 22$. APC is a TSG that controls cell division, cell-cell interactions and cell migration and invasion [4]. APC gene hypermethylation ranged from 27 to $46 \%$ in CCA $[25,28]$. This gene hypermethylation is associated with a worse clinical outcome in CCA patients [25]. The DNA methylation frequencies of other genes related to cell adhesion, including tissue inhibitor of metalloproteinase (TIMP3) $[25,28]$ and thrombospondin 1 (THBS1) [25, 37], as well as their chromosomal locations are shown in table 1 .

The DNA methylation frequencies including retinoic acid receptor- $\beta 2$ (RAR $\beta 2$; function: cell growth and differentiation) [28], glutathione S-transferase pi 1 (GSTP1; function: drug/xenobiotic metabolism) [28], fragile histone triad (FHIT; function: purine metabolism) [33], blunt protein (BLU; function: unknown) [37], methylated in tumor (MINT; function: unknown) [1, 12, 25, 31, 32] as well as their chromosomal locations are shown in table 1.

Suppressor of the cytokine signaling 3 (SOCS3) gene is at chromosome 17q25.3. The expression of this gene is induced by various cytokines, including interleukin (IL)6 , IL-10 and IFN- $\gamma$ [44]. The protein encoded by this gene can bind to and inhibit the activity of Janus kinases, turning off signal transducers and activators of transcription 3 (STAT3) signaling in response to IL-6 [44]. More recently, we have shown that IL-6-mediated sustained STAT3 activation in human CCA is likely due to SOCS3 epigenetic silencing via hypermethylation of CpG islands within its promoter region (fig. 1) [45], and described the outlines below.

\section{Sustained IL-6/STAT3 Signaling in CCA due to}

SOCS3 Epigenetic Silencing

We have previously demonstrated that IL-6-mediated STAT3 signaling is sustained in human CCA cells [46]. Following binding by IL- 6 to its cognate receptor complex, Janus kinases are recruited to the receptor complex and activated [44, 47]. These kinases phosphorylate STAT3 which then dimerizes and translocates to the nucleus where it functions as a transcription factor $[44,47]$. Normally, the STAT3 response to IL-6 stimulation is ter-

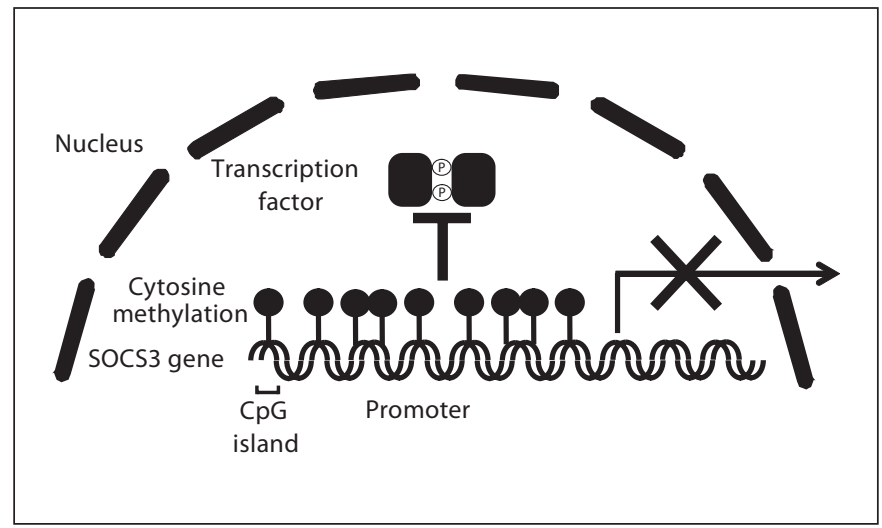

Fig. 1. CpG island hypermethylation of SOCS3 gene promoter inhibits transcription factor-DNA interactions, leading to inhibition of SOCS3 expression.

minated by SOCS3, a negative regulator of IL-6/STAT3 signaling [44]. In a classic feedback loop, STAT3 dimers turn on the SOCS3 gene which then feeds back and inhibits the signaling cascades [44, 47].

We generated the hypothesis that SOCS3 silencing results in sustained IL-6/STAT3 signaling in human CCA cells. Silencing of the SOCS3 gene would, indeed, explain why IL- 6 signaling in these cells is not turned off as in normal cells. In the first place, we sought to investigate the relationship between activated STAT3 and SOCS3 expression in human CCA tissue by immunohistochemistry. We found an inverse relationship between activated STAT3 and SOCS3 cytoplasmic expression in human CCA tissue; STAT3 nuclear immunoreactivity was observed, whereas SOCS3 expression was absent (fig. 2).

Tissue-specific genomic DNA was isolated from the human CCA tissue sections by laser capture microdissection. The genomic DNA was subjected to methylationspecific PCR and then the bisulfite-modified DNA was sequenced. SOCS3 promoter was methylated in human CCA; the methylation-specific PCR showed intense methylation PCR product was observed in the SOCS3 promoter from CCA, while the SOCS3 promoter was unmethylated in paired nonmalignant tissue (uninvolved bile duct epithelial cells and hepatocytes) from the same specimen (fig. 3).

Next, we performed sequencing the bisulfite-modified genomic DNA to assess CpG island methylation directly. DNA enriched for CpG Islands were sequenced between regions -678 and -216 of the promoter. Five random clones were each sequenced. The SOCS3 promoter was densely methylated in the cancer but not in the unin- 
Fig. 2. Inverse correlation between tyrosine $\mathrm{e}^{705}$-phosphorylated STAT3 and SOCS3 expression in human CCA tissue. Arrows indicate intense nuclear localization of activated STAT3 and absent expression of cytoplasmic SOCS3 in the serial sections.
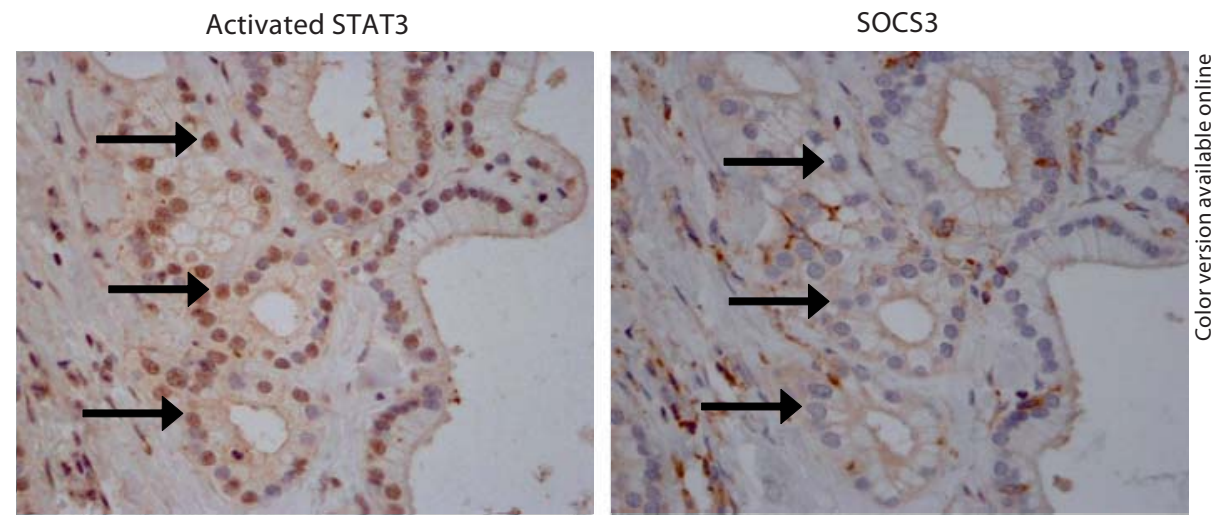

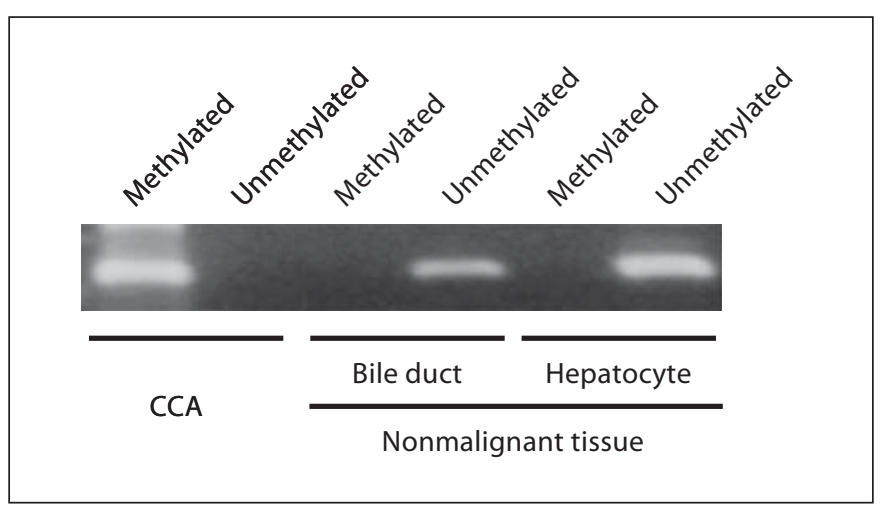

Fig. 3. Methylation-specific PCR was performed using the methylated and unmethylated DNA-specific primer sets. CpG island methylation of the SOCS3 promoter is specific for CCA. Genomic DNA was extracted from paired tumor and nontumor tissue (uninvolved bile duct epithelial cells and hepatocytes) procured by laser capture microdissection.

volved tissue (fig. 4); it would appear that CpG island methylation of the SOCS3 promoter is a potential mechanism for silencing of this gene in human CCA (fig. 1). To ascertain the functional significance of this methylation, we examined a CCA cell line retain the SOCS3 promoter methylation pattern. Employing the malignant $\mathrm{Mz}-\mathrm{ChA}$ 1 cells and the nonmalignant $\mathrm{H} 69$ cells as a control, the methylation status of the SOCS3 promoter was determined by methylation-specific PCR and bisulfite sequencing. CpG island methylation of the SOCS3 promoter was observed in the malignant but not in the nonmalignant cells. Methylation-specific PCR demonstrates a methylated product for the SOCS3 promoter in the cancer cells but not in the nonmalignant cells. Likewise, dense methylation of the $\mathrm{CpG}$ Islands in the promoter

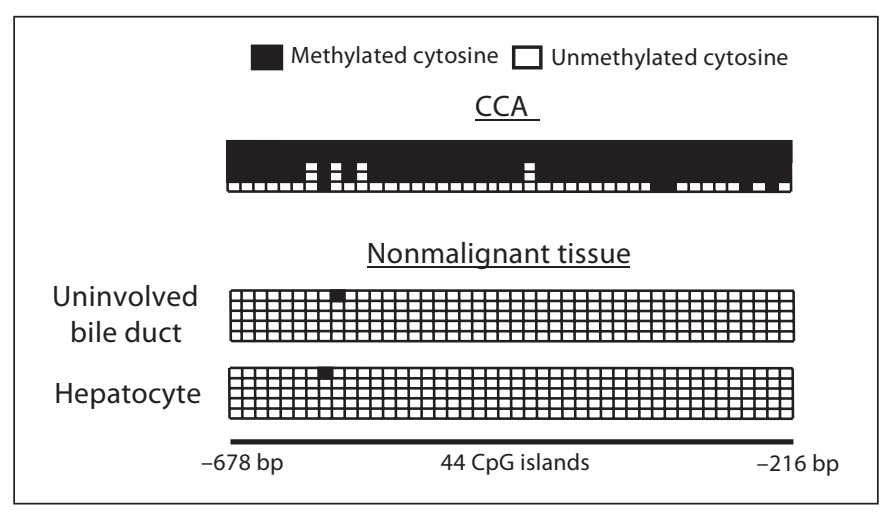

Fig. 4. PCR products were sequenced for the $44 \mathrm{CpG}$ sites located between nucleotides -678 and -216 of the SOCS3 promoter following bisulfate modification. The SOCS3 promoter was densely methylated in the cancer but not in the uninvolved tissue.

region was observed in the cancer cell line but not in the nonmalignant cells. Thus, this CCA cell line retains a similar pattern of SOCS3 promoter methylation as does the human tissue.

To determine whether epigenetic silencing of SOCS3 is responsible for the sustained STAT3 activation by IL-6, the MZ-ChA-1 cells were treated with a demethylating agent, 5-aza-2'-deoxycytidine (DAC) and then the expression of activated STAT3 and SOCS3 was assessed in response to IL- 6 by real-time PCR and immunoblot analysis. SOCS3 was not expressed in these cells unless they were pretreated with DAC, but following exposure to the demethylating agent, IL-6 induced SOCS3 expression (fig. 5). Again, there was a prolonged phospho-STAT3 activation in response to IL-6 when treated with vehicle. In 
Fig. 5. A CCA cell line; MZ-ChA-1 cells were treated with a demethylating agent, DAC, and then the expression of SOCS3 was assessed in response to IL- 6 by realtime PCR and immunoblot analysis. DAC treatment restores SOCS3 expression in response to IL-6 in the cancer cells.

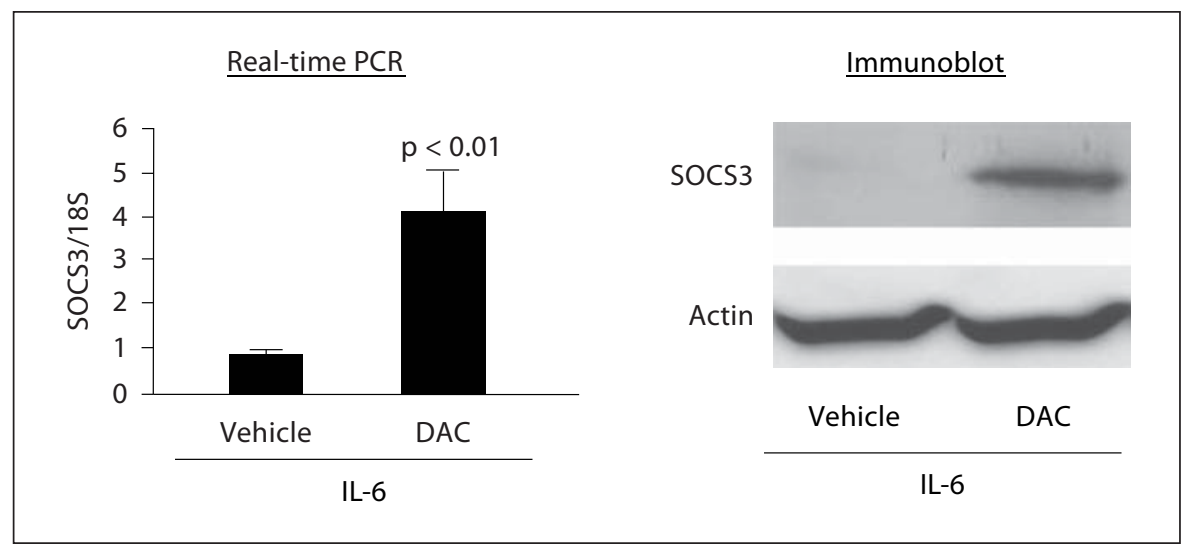

contrast, when the cells are pretreated with DAC, SOCS3 re-expression terminated the phospho-STAT3 signaling event. Thus, the promoter methylation appears to be functional in silencing the SOCS3 gene, and this is a reversible process.

In conclusion, the SOCS3 silencing contributes to the sustained IL-6/STAT3 signaling in CCA cells. The demethylating agents can reverse this process, suggesting that epigenetic therapy may be potentially useful in the treatment of CCA.

\section{Disclosure Statement}

The author declares that no financial or other conflict of interest exists in relation to the content of the article.

\section{References}

1 Lazaridis KN, Gores GJ: Cholangiocarcinoma. Gastroenterology 2005;128:1655-1667.

$\checkmark 2$ Gores GJ: Cholangiocarcinoma: current concepts and insights. Hepatology 2003;37: 961-969.

-3 Shaib YH, El-Serag HB: The epidemiology of cholangiocarcinoma. Semin Liver Dis 2004; 24:115-125.

4 Sandhu DS, Shire AM, Roberts LR: Epigenetic DNA hypermethylation in cholangiocarcinoma: potential roles in pathogenesis, diagnosis and identification of treatment targets. Liver Int 2008;28:12-27.

5 Khan SA, Davidson BR, Goldin R, Pereira SP, Rosenberg WM, Taylor-Robinson SD, Thillainayagam AV, Thomas HC, Thursz MR, Wasan H; British Society of Gastroenterology: Guidelines for the diagnosis and treatment of cholangiocarcinoma: consensus document. Gut 2002;51(suppl 6):VI1-VI9.

-6 Tischoff I, Wittekind C, Tannapfel A: Role of epigenetic alterations in cholangiocarcinoma. J Hepatobiliary Pancreat Surg 2006;13: 274-279.
Kang YK, Kim WH, Lee HW, Lee HK, Kim YI: Mutation of p53 and K-ras, and loss of heterozygosity of APC in intrahepatic cholangiocarcinoma. Lab Invest 1999;79:477483.

8 Yoshida S, Todoroki T, Ichikawa Y, Hanai S, Suzuki H, Hori M, Fukao K, Miwa M, Uchida K: Mutations of p16Ink4/CDKN2 and p15Ink4B/MTS2 genes in biliary tract cancers. Cancer Res 1995;55:2756-2760.

-9 Hahn SA, Bartsch D, Schroers A, Galehdari $\mathrm{H}$, Becker M, Ramaswamy A, SchwarteWaldhoff I, Maschek H, Schmiegel W: Mutations of the DPC4/Smad4 gene in biliary tract carcinoma. Cancer Res 1998;58:11241126.

10 Shiraishi K, Okita K, Kusano N, Harada T, Kondoh S, Okita S, Ryozawa S, Ohmura R, Noguchi T, Iida Y, Akiyama T, Oga A, Fukumoto Y, Furuya T, Kawauchi S, Sasaki K: A comparison of DNA copy number changes detected by comparative genomic hybridization in malignancies of the liver, biliary tract and pancreas. Oncology 2001;60:151-161.
11 Kawaki J, Miyazaki M, Ito H, Nakagawa K, Shimizu H, Yoshidome H, Uzawa K, Tanzawa H, Nakajima N: Allelic loss in human intrahepatic cholangiocarcinoma: correlation between chromosome $8 \mathrm{p} 22$ and tumor progression. Int J Cancer 2000;88:228-231.

12 Roth SY, Denu JM, Allis CD: Histone acetyltransferases. Annu Rev Biochem 2001;70: 81-120.

13 Thiagalingam S, Cheng KH, Lee HJ, Mineva N, Thiagalingam A, Ponte JF: Histone deacetylases: unique players in shaping the epigenetic histone code. Ann NY Acad Sci 2003;983:84-100.

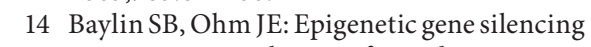
in cancer - a mechanism for early oncogenic pathway addiction? Nat Rev Cancer 2006;6: 107-116.

15 Konishi K, Issa JP: Targeting aberrant chromatin structure in colorectal carcinomas. Cancer J 2007;13:49-55.

16 Pandolfi PP: Histone deacetylases and transcriptional therapy with their inhibitors. Cancer Chemother Pharmacol 2001;48(suppl 1):S17-S19. 
17 Bird A: DNA methylation patterns and epigenetic memory. Genes Dev 2002;16:6-21.

18 Cooper DN, Gerber-Huber S: DNA methylation and CpG suppression. Cell Differ 1985; 17:199-205.

19 Riggs AD, Pfeifer GP: X-chromosome inactivation and cell memory. Trends Genet 1992;8:169-174.

20 Razin A, Cedar H: DNA methylation and genomic imprinting. Cell 1994;77:473-476.

21 Clouaire T, Stancheva I: Methyl-CpG binding proteins: specialized transcriptional repressors or structural components of chromatin? Cell Mol Life Sci 2008;65:15091522.

-22 Herman JG, Baylin SB: Gene silencing in cancer in association with promoter hypermethylation. N Engl J Med 2003;349:20422054.

-23 Esteller M, Corn PG, Baylin SB, Herman JG: A gene hypermethylation profile of human cancer. Cancer Res 2001;61:3225-3229.

-24 Serrano M, Hannon GJ, Beach D: A new regulatory motif in cell-cycle control causing specific inhibition of cyclin D/CDK4. Nature 1993;366:704-707.

-25 Lee S, Kim WH, Jung HY, Yang MH, Kang $\mathrm{GH}$ : Aberrant $\mathrm{CpG}$ island methylation of multiple genes in intrahepatic cholangiocarcinoma. Am J Pathol 2002;161:1015-1122.

-26 Tozawa T, Tamura G, Honda T, Nawata S, Kimura W, Makino N, Kawata S, Sugai T, Suto T, Motoyama T: Promoter hypermethylation of DAP-kinase is associated with poor survival in primary biliary tract carcinoma patients. Cancer Sci 2004;95:736-740.

27 Ahrendt SA, Eisenberger CF, Yip L, Rashid A, Chow JT, Pitt HA, Sidransky D: Chromosome 9p21 loss and p16 inactivation in primary sclerosing cholangitis-associated cholangiocarcinoma. J Surg Res 1999;84:88-93.

-28 Yang B, House MG, Guo M, Herman JG, Clark DP: Promoter methylation profiles of tumor suppressor genes in intrahepatic and extrahepatic cholangiocarcinoma. Mod Pathol 2005; 18:412-420. $\checkmark 29$ Klump B, Hsieh CJ, Dette S, Holzmann K, Kiebetalich R, Jung M, Sinn U, Ortner M, Porschen R, Gregor M: Promoter methylation of INK4a/ARF as detected in bile-significance for the differential diagnosis in biliary disease. Clin Cancer Res 2003;9: 1773-1778.

30 Koga Y, Kitajima Y, Miyoshi A, Sato K, Kitahara K, Soejima H, Miyazaki K: Tumor progression through epigenetic gene silencing of $\mathrm{O}(6)$-methylguanine-DNA methyltransferase in human biliary tract cancers. Ann Surg Oncol 2005;12:354-363.

31 Hong SM, Choi J, Ryu K, Ro JY, Yu E: Promoter hypermethylation of the p16 gene and loss of its protein expression is correlated with tumor progression in extrahepatic bile duct carcinomas. Arch Pathol Lab Med 2006 130:33-38.

32 Tannapfel A, Sommerer F, Benicke M, Weinans L, Katalinic A, Geissler F, Uhlmann D, Hauss J, Wittekind C: Genetic and epigenetic alterations of the INK4a-ARF pathway in cholangiocarcinoma. J Pathol 2002;197: 624-631.

-33 Foja S, Goldberg M, Schagdarsurengin U, Dammann R, Tannapfel A, Ballhausen WG: Promoter methylation and loss of coding exons of the fragile histidine triad (FHIT) gene in intrahepatic cholangiocarcinomas. Liver Int 2005;25:1202-1208.

34 Wong N, Li L, Tsang K, Lai PB, To KF, Johnson PJ: Frequent loss of chromosome $3 p$ and hypermethylation of RASSF1A in cholangiocarcinoma. J Hepatol 2002;37:633-639.

35 Raveh T, Kimchi A: DAP kinase-a proapoptotic gene that functions as a tumor suppres sor. Exp Cell Res 2001;264:185-192.

-36 Liu XF, Zhu SG, Zhang H, Xu Z, Su HL, Li SJ, Zhou XT: The methylation status of the TMS1/ASC gene in cholangiocarcinoma and its clinical significance. Hepatobiliary Pancreat Dis Int 2006;5:449-453.

37 Tischoff I, Markwarth A, Witzigmann H, Uhlmann D, Hauss J, Mirmohammadsadegh A, Wittekind C, Hengge UR, Tannapfel A: Allele loss and epigenetic inactivation of 3 p21.3 in malignant liver tumors. Int J Cancer 2005;115:684-689.
38 Fishel R, Kolodner RD: Identification of mismatch repair genes and their role in the development of cancer. Curr Opin Genet Dev 1995;5:382-395.

39 Kane MF, Loda M, Gaida GM, Lipman J, Mishra R, Goldman H, Jessup JM, Kolodner $\mathrm{R}$ : Methylation of the hMLH1 promoter correlates with lack of expression of hMLH1 in sporadic colon tumors and mismatch repairdefective human tumor cell lines. Cancer Res 1997;57:808-811.

-40 Abraham SC, Lee JH, Boitnott JK, Argani P, Furth EE, Wu TT: Microsatellite instability in intraductal papillary neoplasms of the biliary tract. Mod Pathol 2002;15:1309-1317.

41 Limpaiboon T, Khaenam P, Chinnasri P, Soonklang M, Jearanaikoon P, Sripa B, Pairojkul C, Bhudhisawasdi V: Promoter hypermethylation is a major event of hMLH1 gene inactivation in liver fluke related cholangiocarcinoma. Cancer Lett 2005;217:213-219.

42 Casorelli I, Russo MT, Bignami M: Role of mismatch repair and MGMT in response to anticancer therapies. Anticancer Agents Med Chem 2008;8:368-380.

43 Stemmler MP: Cadherins in development and cancer. Mol Biosyst 2008;4:835-850.

44 Kubo M, Hanada T, Yoshimura A: Suppressors of cytokine signaling and immunity. Nat Immunol 2003;4:1169-1176.

$\checkmark 4$ Isomoto H, Mott JL, Kobayashi S, Werneburg NW, Bronk SF, Haan S, Gores GJ: Sustained IL-6/STAT-3 signaling in cholangiocarcinoma cells due to SOCS-3 epigenetic silencing. Gastroenterology 2007;132:384396.

$\checkmark 46$ Isomoto H, Kobayashi S, Werneburg NW, Bronk SF, Guicciardi ME, Frank DA, Gores GJ: Interleukin 6 upregulates myeloid cell leukemia-1 expression through a STAT3 pathway in cholangiocarcinoma cells. Hepatology 2005;42:1329-1338.

47 Heinrich PC, Behrmann I, Haan S, Hermanns HM, Müller-Newen G, Schaper F: Principles of interleukin (IL)-6-type cytokine signalling and its regulation. Biochem J 2003;374:1-20. 